УДК 338.4:620.95:631.11(477)

\title{
РЕГУЛЯТОРНІ ІНСТРУМЕНТИ СТИМУЛЮВАННЯ РОЗВИТКУ ВИРОБНИЦТВА БІОПАЛИВ ПІДПРИЄМСТВАМИ АПК В УКРАЇНІ
}

\author{
Резнік Н.П., д.е.н., професор, \\ Гаврилюк Ю.Г., аспірант (НУБіП), \\ Музиченко А.С., д.е.н., професор (ЦНТУ)
}

\begin{abstract}
У статті розглянуто законодавчо-нормативні акти, щуо регулюють процес виробництва біопалив підприємствами України. Проаналізовано та висвітлено ряд заходів із державної підтримки підприємств у сфері енергоефективності України. Окреслено основні інструменти стимулювання розвитку виробництва біопалив підприємствами АПК в Україні.

На основі проведеного дослідження, в якості стратегічного напрямку, запроновано ряд переваг кластерної організації для підвищення конкурентоспроможності підприємств з виробництва біопалива, щзо виконується через впровадження інновачійних розробок у сфері біоенергетики та входять до кластерів.
\end{abstract}

Ключові слова: біопалива, енергетика, державна підтримка, державноприватне партнерство

\section{РЕГУЛЯТОРНЫЕ ИНСТРУМЕНТЫ СТИМУЛИРОВАНИЯ РАЗВИТИЯ ПРОИЗВОДСТВА БИОТОПЛИВА ПРЕДПРИЯТИЯМИ АПК В УКРАИНЕ}

\author{
Резник Н.П. д.э.н., профессор, \\ Гаврылюк Ю.Г. аспирант (НУБиП), \\ Музыченко А.С. о.э.н., профессор (ЦНТУ)
}

\begin{abstract}
В статье рассмотрены законодательно-нормативные акты, регулируюшие проиесс производства биотоплива предприятиями Украины. Проанализированы и освещены ряд мероприятий по государственной поддержке предприятий в сфере энергоэффективности Украины. Определень основные инструменты стимулирования развития производства биотоплива предприятиями АПК в Украине.

На основе проведенного исследования, в качестве стратегического направления, предложено ряд преимуществ кластерной организации для повышения конкурентоспособности предприятий по производству биотоплива, что выполняется через внедрение инноваџионных разработок в сфере биоэнергетики и которые входят в кластеры.
\end{abstract}

Ключевые слова: биотопливо, энергетика, государственная поддержска, государственно-частное партнерство.

(C) Резнік Н.П., Гаврилюк Ю.Г., Музиченко А.C. 


\title{
DIVERSIFICATION OF RENEWABLE ENERGY SOURCES BY AGRICULTURAL ENTERPRISES IN UKRAINE
}

\author{
Reznik N.P. Doctor of Economic Sciences, professor, \\ Gavrylyuk Y.G. postgraduate \\ (National University of Life and Environmental Sciences of Ukraine), \\ Muzychenko A.S. Doctor of Economic Sciences, professor \\ (Central Ukrainian Scientific and Technical University)
}

The article deals with the legislative and regulatory acts governing the process of biofuels production by Ukrainian enterprises. A number of measures for state support of enterprises in the field of energy efficiency of Ukraine have been analyzed and reported. The main instruments for stimulating the development of biofuels production by agricultural enterprises in Ukraine are outlined.

On the basis of the conducted research, as a strategic direction, a number of advantages of the cluster organization for enhancing the competitiveness of biofuels enterprises implemented through the implementation of innovative developments in the field of bioenergy and included in clusters

The article deals with the interpretation of content filling of processes of cooperation, horizontal and vertical integration and cluster organization of production in the system of enterprises for the production of oilseeds and products of their processing.

A system of measures on possible options for efficient production of biofuels and restraint of growing areas of oilseed crops is proposed.

The prospects of building an effective entrepreneurial environment in the field of biofuel production have been determined, provided the formation of functional economic mechanisms for its stimulation, in particular: cheaper loans; exemption from taxation of a part of the profit received from the introduction of energy efficient and energy-saving technologies.

The analysis of the literature has made it possible to determine that the problems of the efficiency of production of oilseeds in the context of systematic assessment of the ecological consequences of the processes of development of agricultural enterprises and export orientation of the oil and fat subcomplex remain insufficiently covered.

Key words: biofuels, energy, state support, public-private partnership.

Постановка проблеми. Сьогодні енергомісткість ВВП Використання поновлюваних джерел країни у 2 рази перевищує енергії $\epsilon$ одним із важливих напрямів середньосвітовий рівень та понад 3 рази $\epsilon$ енергетичної політики України, спрямованої на заощадження традиційних паливно-енергетичних ресурсів та поліпшення стану оточуючого природного середовища. Збільшення обсягів використання ПДЕ в енергетичному балансі країни дозволяє підвищувати рівень диверсифікації джерел енергоносіїв, що сприятиме зміцненню енергетичної незалежності держави. вищою, ніж у СС. Вуглецеємність ВВП за даними 2014 р. понад 2 рази перевищувала світовий показник, у 2,6 раза була вище середнього значення по країнах ОЕСР та у 3,8 раза - по країнах ЄС. Це пов'язано переважно 3 низькою ефективністю використання паливно-енергетичних ресурсів у технологічних процесах (переважно енергоємних галузей), незадовільним станом енергетичної інфраструктури, значними втратами під

Вісник економіки транспорту і промисловості № 69,2020 
час перетворення, передавання та розподілення енергії, низьким коефіцієнтом корисної дії обладнання у секторах кінцевого споживання, а також із недостатньою ефективністю природоохоронних засобів.

Аналіз останніх досліджсень та публікацій. Проблеми функціонування та економічного розвитку підприємств 3 виробництва олійних культур і продуктів ïx переробки висвітлено у працях відомих вітчизняних і зарубіжних учених, зокрема М. Е. Браславця, Р.Г. Кравченка [1], О. М. Варченко [2], М. М. Ільчука, М. В. Калінчика [4], Г. М. Калетніка [5], С. П. Капшука [6], В. Я. Месель-Веселяка [7, 8], О. П. Скорука [10] та ін.

Виділення невирішених частин загальної проблеми. Попри існуючий науковий доробок не знайшли системного дослідження аналіз стану та перспектив розвитку виробництва біопалив, а також моделювання організаційно-економічних сценаріїв виробництва біопалив та вибір альтернативного його варіанта.

Метою cmammi $€$ визначення інструментів стимулювання виробництва біопалив підприємствами України на основі аналізу законодавчо-нормативних актів, які регулюють процес виробництва біопалив підприємствами України.

Виклад основного матеріалу. Неефективне внутрішнє споживання паливно-енергетичних ресурсів підвищує рівень залежності від країн-експортерів і поглиблюе проблему енергетичної безпеки країни за рівнем імпортозалежності понад $51 \%$ при нереалізованому потенціалі енергозбереження в Україні до 48\% від обсягу споживаних паливно-енергетичних ресурсів.

Україна, ставши повноправним членом Енергетичного Співтовариства 3 01.02.2011 p., відповідно до Закону України від 15.12.2010 р. №2787-VI «Про ратифікацію Протоколу про приєднання України до Договору про заснування Енергетичного Співтовариства» прийняла зобов'язання щодо імплементації основних актів енергетичного законодавства Європейського Союзу.

На виконання ухваленого в жовтні 2012 p. Рішення Ради Міністрів Енергетичного Співтовариства D/2012/04/MC-EnC Про впровадження Директиви 2009/28/ЕС про заохочення до використання енергії, виробленої 3 відновлюваних джерел Україна взяла на себе зобов'язання до 2020 р. довести рівень енергії, виробленої з поновлюваних джерел енергії в загальній структурі енергоспоживання країни до $11 \%$, що дозволить до 2020 p. зменшити використання традиційних первинних енергоресурсів в обсязі 8,6 млн т н.е. (9,2 млрд м ${ }^{3}$ природного газу).

Основними законодавчими актами в Україні, якими регулюється використання поновлюваних джерел енергії є:

- Закони України: від 25.06.1991 p. №1264-ХІІ (у редакції від 04.06.2017 $\quad$ р.) «Про охорону навколишнього природного середовища»; від 01.07.1994 р. №74/94 ВР (у редакції від 23.07.2017 р.) «Про енергозбереження»; від 05.03.1998 р. №187/98-ВР (у редакції від 09.05.2016 р.) «Про відходи»; від 14.01.2000 р. №1391-XIV (у редакції від 24.11 .2016 р.) «Про альтернативні види палива»; від 20.02.2003 р. №555-IV (у редакції від 11.06.2017 р.) «Про альтернативні джерела енергії»; від 05.04.2005 p. №2509-IV (у редакції від 26.11 .2016 р.) «Про комбіноване виробництво теплової та електричної енергії (когенерацію) та використання скидного енергопотенціалу»; від 02.06.2005 p. №2633-IV (у редакції від 02.08.2017 р.) «Про теплопостачання»; від 21.05.2009 p. №1391-VI (у редакції від 28.06 .2015 р.) «Про внесення змін до деяких законів України щодо сприяння виробництву та використанню біологічних видів палива»; від 23.05.2017 р. №2059VIII «Про оцінку впливу на довкілля» (введення в дію 18.12. 2017 р.) тощо. 
- $\quad$ Лісовий кодекс України від 21.01.1994 р. №3852-XII (у редакції від• 03.09.2017 p.);

\section{- $\quad$ Постанова}

Кабінету

Міністрів України: від 05.10.2004 р. №1307 (у• редакції від 18.08.2011р.) «Про порядок видачі свідоцтва про належність палива до альтернативного» тощо.

- Указом Президента України від 12.01.2015 p. №5/2015 схвалено Стратегію сталого розвитку «Україна 2020».

Згідно 3 положенням Стратегії, основними цілями державної політики у cфepi енергонезалежності, енергоефективності та екології є:

до кінця 2020 р. Зниження енергомісткості ВВП на 20\% шляхом переходу до використання енергоефективних технологій та обладнання;

\begin{tabular}{lcr}
\multicolumn{3}{c}{ енергоощадного } \\
використання & та & споживання \\
енергоресурсів & iз & впровадженням \\
iнноваційних технологій; &
\end{tabular}

$\begin{array}{lr}>\quad \text { забезпечення } & 100 \% \\ \text { обов'язкового комерційного } & \text { обліку } \\ \text { споживання енергоресурсів; } & \end{array}$

$>$ реалізації проектів 3 використанням альтернативних джерел енергії тощо.

Згідно з чинним законодавством в Україні діє система стимулювання розвитку поновлюваної енергетики яка включає «зелені» тарифи в євро, диференційовані за типом та потужністю об'єктів, а також за строками введення в експлуатацію об'єктів енергетики. Державою підтверджено обов'язковість купівлі електроенергії поновлюваних джерел енергії за «зеленим» тарифом до 2030 року; скасовано вимогу щодо «місцевої складової» і введено надбавку до тарифу за використання українського обладнання; передбачено укладення довгострокових договорів купівліпродажу електроенергії, виробленої за «зеленим» тарифом, на весь термін дії цього тарифу.
Законодавчими та нормативноправовими актами України передбачено ряд видів державної підтримки підприємств і господарств у сфері енергоефективності: пряме бюджетне фінансування; звільнення від ПДВ, ввізного мита; звільнення частини прибутку від оподаткування; установлення економічно обгрунтованих тарифів на комунальні послуги; надання державних гарантій під кредитні лінії, відкриті в кредитних установах. Впроваджуються також схеми державної підтримки населення для придбання опалювального обладнання, що не використовує природний газ як паливо.

Енергетичною стратегією України на період до 2035 року «Безпека, енергоефективність,

конкурентоспроможність» (ЕСУ-2035), схваленою розпорядженням Кабінету Міністрів України від 18.08.2017 р. №605$\mathrm{p}$, визначено мету i цілі розбудови енергетичного сектору відповідно до потреб економічного i соціального розвитку країни на період до 2035 р.

Головною метою розвитку енергетики на період до 2035 p. $\epsilon$ забезпечення енергетичної та екологічної безпеки і перехід до енергоефективного та енергоощадного використання i споживання енергоресурсів із впровадженням інноваційних технологій.

Прогнозується зниження енергоємності ВВП (ПКС) з 0,28 т н.е./тис. дол. США у 2015 р. до 0,13 т н.е./тис. дол. США у 2035 p.

Частка імпортних компонентів у Загальному первинному постачанні енергіі (ЗППЕ) знизиться до $<50 \%$ вже до 2020 року та до $<33 \%$ у 2025 - 2035 рр., зокрема, завдяки розвитку ПДЕ; збільшенню власного видобутку природного газу; енергозбереженню та підвищенню енергоефективності 3 дотриманням високих екологічних стандартів.

Відповідно до прогнозної структури ЗППЕ обсяги використання викопних 
ресурсів зменшаться у 2035 р. порівняно 3 2015 p., а поновлювані ресурси збільшаться за цей період на 21\%.

У сфері поновлюваних джерел енергії передбачено стале розширення використання всіх видів поновлюваної енергетики.
Орієнтовний прогноз виробництва електроенергії у 2035 р. становитиме 195,0 млрд кВт.год. 3 них: АЕС - 48\%; ТЕС, ТЕЦ - 32\%; ГЕС, ГАЕС - 7\%; ВЕС, СЕС 13\%.(див. таб 1.)

Структура ЗППЕ Украӥни, млн т н.е.,\%*

\begin{tabular}{|l|c|c|c|c|c|}
\hline $\begin{array}{c}\text { Нервинного постачання } \\
\text { енергії }\end{array}$ & $\begin{array}{c}2015 \\
\text { факт }\end{array}$ & $\begin{array}{c}2020 \\
\text { прогно3 }\end{array}$ & $\begin{array}{c}2025 \\
\text { прогно3 }\end{array}$ & $\begin{array}{c}2030 \\
\text { прогно3 }\end{array}$ & $\begin{array}{c}2035 \\
\text { прогно3 }\end{array}$ \\
\hline Вугілля & $27,3 / 30,4$ & $18,0 / 22,0$ & $14,0 / 6,1$ & $13,0 / 14,3$ & $12,0 / 12,5$ \\
\hline Природний газ & $26,1 / 29,0$ & $24,3 / 29,3$ & $27,0 / 31,0$ & $28,0 / 30,8$ & $29,0 / 30,2$ \\
\hline Нафтопродукти & $10,5 / 11,6$ & $9,5 / 11,5$ & $8,0 / 9,2$ & $7,5 / 8,2$ & $7,0 / 7,3$ \\
\hline Атомна енергія & $23,0 / 25,5$ & $24,0 / 29,3$ & $28,0 / 32,2$ & $27,0 / 29,7$ & $24,0 /, 25,0$ \\
\hline $\begin{array}{l}\text { Біомаса, біопаливо та } \\
\text { відходи }\end{array}$ & $2,1 / 2,3$ & $4,0 / 4,9$ & $6,0 / 6,9$ & $8,0 / 8,8$ & $11,0 / 11,5$ \\
\hline $\begin{array}{l}\text { Сонячна таргія } \\
\text { енерге }\end{array}$ & $0,1 / 0,1$ & $1,0 / 1,2$ & $2,0 / 2,4$ & $5,0 / 5,5$ & $10,0 / 10,4$ \\
\hline ГЕС вітрова & $0,5 / 0,5$ & $1,0 / 1,2$ & $1,0 / 1,1$ & $1,0 / 1,1$ & $1,0 / 1,0$ \\
\hline Термальна енергія** & $0,5 / 0,6$ & $0,5 / 0,6$ & $1,0 / 1,1$ & $1,5 / 1,6$ & $2,0 / 2,1$ \\
\hline Всього & $90,1 / 100$ & $82,3 / 100$ & $87,0 / 100$ & $91,0 / 100$ & $96,0 / 100$ \\
\hline
\end{tabular}

ЕСУ-2035 передбачено зростання частки сектору енергетичної галузі, який використовує тверду біомасу та біогаз як енергоресурс, що зумовлюватиметься як відносною сталістю виробництва (за наявності ресурсної бази), так i тенденцією до формування локальних генерувальних потужностей. Перевага віддаватиметься одночасному виробництву теплової та електричної енергії в когенераційних установках i заміщенню вуглеводневих видів палива. Зокрема, передбачено будівництво та введення 5 ГВт потужностей ПДЕ (окрім ГЕС великої потужності); збільшення використання біомаси у генерації електрота теплоенергії шляхом стимулювання використання біомаси як палива на підприємствах, де біомаса є залишковим продуктом; інформування про можливості використання біомаси як палива в індивідуальному сприяння створенню конкурентних ринків біомаси тощо.

У сфері теплопостачання на альтернативних видах палива прогнозується збільшення їх частки у місцевих паливно-енергетичних балансах з $10 \%$ у 2020 р. до $20 \%$ у 2035 р. від загального споживання.

Питомі витрати при виробництві тепла котельнями зменшаться 3165 кг у.п./Гкал у 2015 р. до 145 кг у.п./Гкал у 2035 р. Частка втрат у тепломережах зменшиться з $>20 \%$ у 2015 р. до $>10 \%$ у $2035 \mathrm{p}$.

Важливу роль у виконанні декарбонізації енергетики буде відігравати розширення використання джерел усіх видів поновлюваної енергетики, які мають найбільш низькі викиди парникових газів.

Викиди $\mathrm{CO}_{2}$ до рівня 1990 р. зменшаться $3<60 \%$ у 2020 р. до $<50 \%$ у 2035 р. Частка потужностей у тепловій 
генерації, що відповідає вимогам $Є \mathrm{C}$ (викиди $\mathrm{CO}_{2}, \mathrm{NO}_{\mathrm{x}}$, золи), які становили у 2015 р. $<1 \%$ у 2035 р. досягнуть $100 \%$.

На організацію виконання завдань та зобов'язань України, як члена Енергетичного Співтовариства, імплементації Директив ЄС 3 питань розвитку та впровадження поновлюваних джерел енергії, підвищення ефективності та екологічності використання енергетичних ресурсів вважати за необхідне:

створення

Технічного комітету 3 стандартизації біоенергетики, палива та обладнання, метою якого буде імплементація/гармонізація сучасних європейських та міжнародних стандартів та прийнятті їх в якості державних стандартів;

розроблення та введення в дію технологічних нормативів щодо допустимих викидів в атмосферне повітря забруднюючих речовин, які утворюються при роботі теплогенерувального обладнання, що використовує біопаливо для теплопостачання населених пунктів;

$$
\text { створення в країні }
$$

конкурентних ринків теплової енергії та біопалива;

$$
\text { розроблення }
$$

системи стимулювання промислових підприємств до енергоефективності; розвитку високоефективної когенерації; доступу до мереж виробникам «зеленої» електроенергії;

розроблення типової моделі БіоЕС $з$ виробництва енергії $з$ відходів у країні;

стимулювання будівництва підприємств 3 виробництва пелет; заводів 3 виробництва котлів, що працюють на біопаливі; підприємств 3 виробництва біоетанолу другого покоління; сміттєпереробних заводів; вирощування енергетичних культур;

запровадження

єдиної

системи статистики щодо збору та аналізу стану основних складових біоенергетики країни тощо.
В якості стратегічного напрямку на сьогодні, нами пропонується збільшення конкурентоспроможності виробництва біопалива, яке виконується через впровадження інноваційних розробок у сфері біоенергетики, що входять до кластерів. Виділяють ряд переваг кластерної організації в системі агроформувань, що дозволяє інвестувати у власні підприємства в безпосередній близькості від полів агрогосподарств в умовах дефіциту якісної інфраструктури для зберігання олійних на ринку із застосуванням інноваційних технологій. Інвестиційний ризик, який характеризує невизначеність кінцевого результату інвестицій. Рівень потенційного відхилення реального результату від прогнозуючого повинен певним чином оцінюватися корисною мірою ризику.

Виділяють такі різновиди інноваційного ризику 3 позиції інвестування, як:

$>$ 1)ризик зниження доходу причинами виникнення яких $є$ зниження розміру відсотків та дивідендів по портфельним інвестиціям;

$>$ 2) ризики прямих фінансових втрат складаються із таких різновидів, як:

$\begin{array}{ccc}\bullet & \text { селективний ризик } & - \text { ризик } \\ \text { неправильного } & \text { обраного } & \text { способу }\end{array}$ вкладення капіталу;

- ризик банкрутства небезпека в результаті неправильно обраного способу вкладення капіталу, повної втрати власного підприємницького капіталу та його неспроможності розрахуватися взятими на себе обов'язками;

$$
\text { - кредитний ризик - }
$$
можливість відсутності виплат зі сторони позичальника основного боргу та відсотків, передбаченого для передачі інвестору. Оцінка даного ризику виробляється інвестором самостійно.

Для розвитку привабливих агропромислових кластерних формувань необхідна активна державна політика. 
Активна державна політика в даному випадку обумовлена неможливістю підприємницьких структур подолати обмеження по збільшенню залучених інвестицій, пов'язаних $з$ низьким рівнем галузевого розвитку.

В засаді аналізу проектів, які реалізуються в регіоні, область їх застосування, підхід до їх здійснення можливо говорити про те, що такі існуючі механізми, державно-приватне партнерство, засоби інститутів розвитку, організаційні, управлінські та фінансові ресурси бізнесу, іноземні інвестиції, регіональні бюджетні засоби могли б використовуватися в великих масштабах. Випадки, при яких виникає скоординована взаємодія бізнесу та влади, спрямованої на розвиток регіонів та окремих галузей посередництвом таких механізмів, небагато численні.

На загальному та місцевому рівнях виділяють наступні проблеми, які перешкоджають здійсненню ефективної взаємодії держави, інвесторів та підприємницького середовища в рамках ДПП (державно-приватне партнерство в галузі біоенергетики):

не відпрацювання єдиних правових норм, на основі яких була б можлива реалізація інвестиційних проектів із застосуванням різних форм державно - приватного партнерства.

задіяні в ДПП.

нерівноправність сторін, які

$>\quad$ не сформованість концепції розвитку та підтримки ДПП.

Нами сформована модель ДПП, яка включає не тільки державу та бізнес, але й іноземних інвесторів, розглянемо основні різновиди реалізації партнерства (рис. 1).

В широкому сенсі, державноприватне партнерство - це форма пропозиції державних послуг, які поєднують приватний та державний сектор на довготривалій контрактній основі, яка покладає на кожну із сторін певні обов'язки.
У відповідності 3 розглянутими особливостями ДПП, базовими ознаками подібної форми відносин $є$ :

1. Сторонами ДПП є держава та приватний бізнес.

2. Взаємовідносини сторін носять партнерський, рівноправний характер.

3. Сторони мають загальні цілі, чітко виражений державний інтерес та громадську спрямованість.

4. Сторони об'єднують власні активи (ресурси та внески) для досягнення спільних цілей.

5. Сторони ДПП розподіляють між собою витрати та ризики в раніше узгоджених пропорціях, а також приймають участь у використанні отриманих результатів.

6. Взаємовідносини сторін зафіксовані в офіційних документах (договорах, контрактах та ін.).

Основні особливості формування відносин між державою та приватним бізнесом при реалізації різних форм ДПП представлені у таблиці 2.

Основними проблемами, які перешкоджають розвитку державноприватного партнерства в Україні є:

відсутність єдиної державної політики по розвитку державноприватного партнерства та спеціального державного органу, що контролює ці питання;

непрозорість процедур відбору проектів для реалізації в рамках ДПП, а також відкритих конкурсів на право заключення угоди про ДПП;

відсутність громадського контролю за реалізацією ДПП-проектів;

неможливість

кредитування бізнесу.

Схематично реалізація концесійних угод зображена на рис 2.

Для підвищення інвестиційної привабливості безперспективних сфер діяльності розроблена модель регулювання діяльності кластерних структур (рис. 3) посередництвом проведення активної державної політики. 


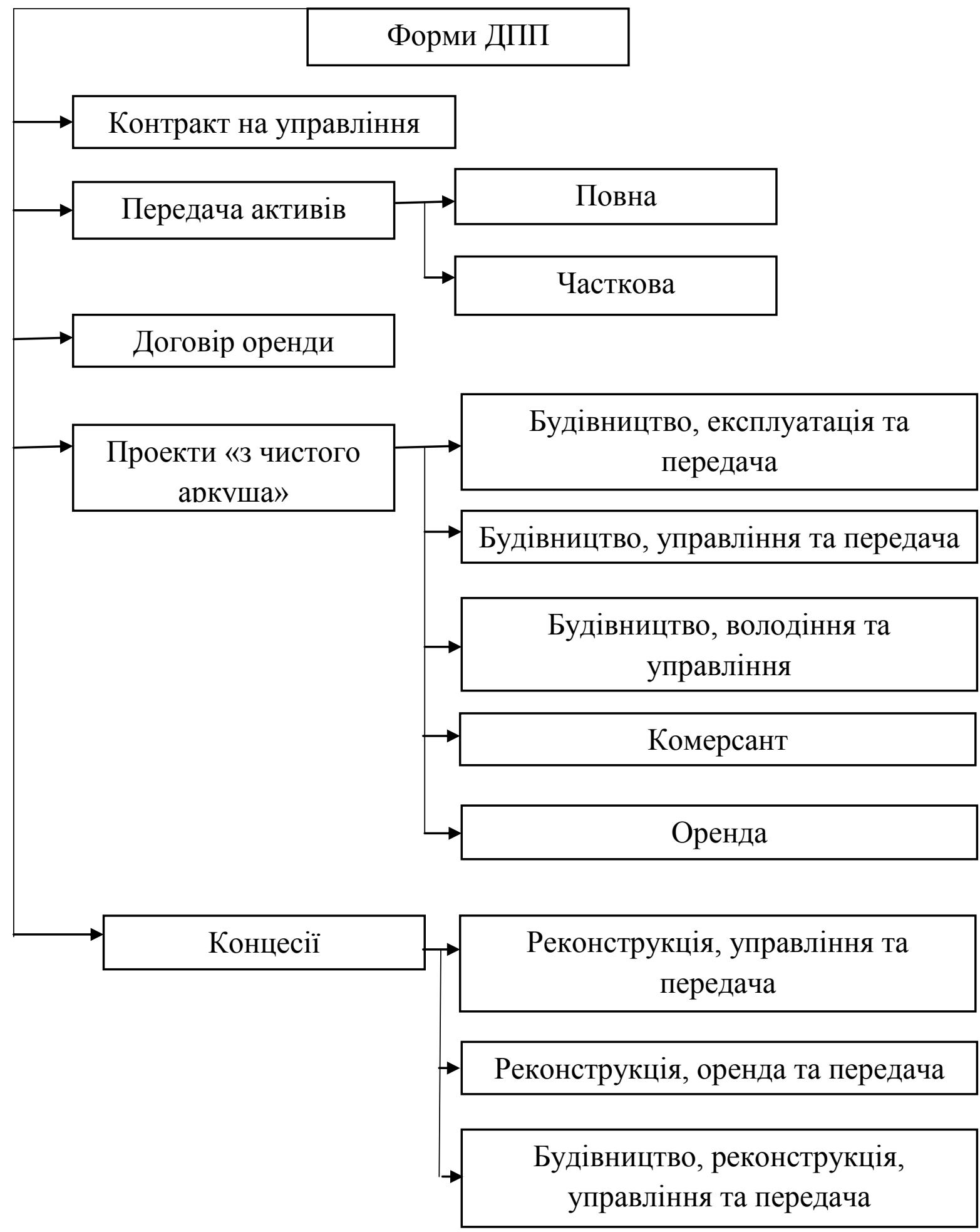

Примітка* Розроблено автором

Рис. 1 Основні форми ДПП* 
Таблиияя 2

Оиінка форм державно-приватного партнерства через розподілення ризиків*

\begin{tabular}{|c|c|c|c|c|}
\hline Ризики/Форми & $\begin{array}{c}\text { Управління та } \\
\text { експлуатація }\end{array}$ & $\begin{array}{c}\text { Оплата } \\
\text { послуг }\end{array}$ & Інвестування & $\begin{array}{c}\text { Власність на } \\
\text { активи }\end{array}$ \\
\hline $\mathbf{1}$ & $\mathbf{2}$ & $\mathbf{3}$ & $\mathbf{4}$ & $\mathbf{5}$ \\
\hline Договір підряду & влада & влада & влада & влада \\
\hline $\begin{array}{c}\text { Контракт на } \\
\text { управління }\end{array}$ & оператор & влада & влада & влада \\
\hline Договір оренди & оператор & оператор & влада & влада \\
\hline Концесія & оператор & оператор & оператор & влада \\
\hline Приватизація & оператор & оператор & оператор & $\begin{array}{c}\text { влада } \\
\text { оператор }\end{array}$ \\
\hline
\end{tabular}

Примітка. * Сформовано за [5]

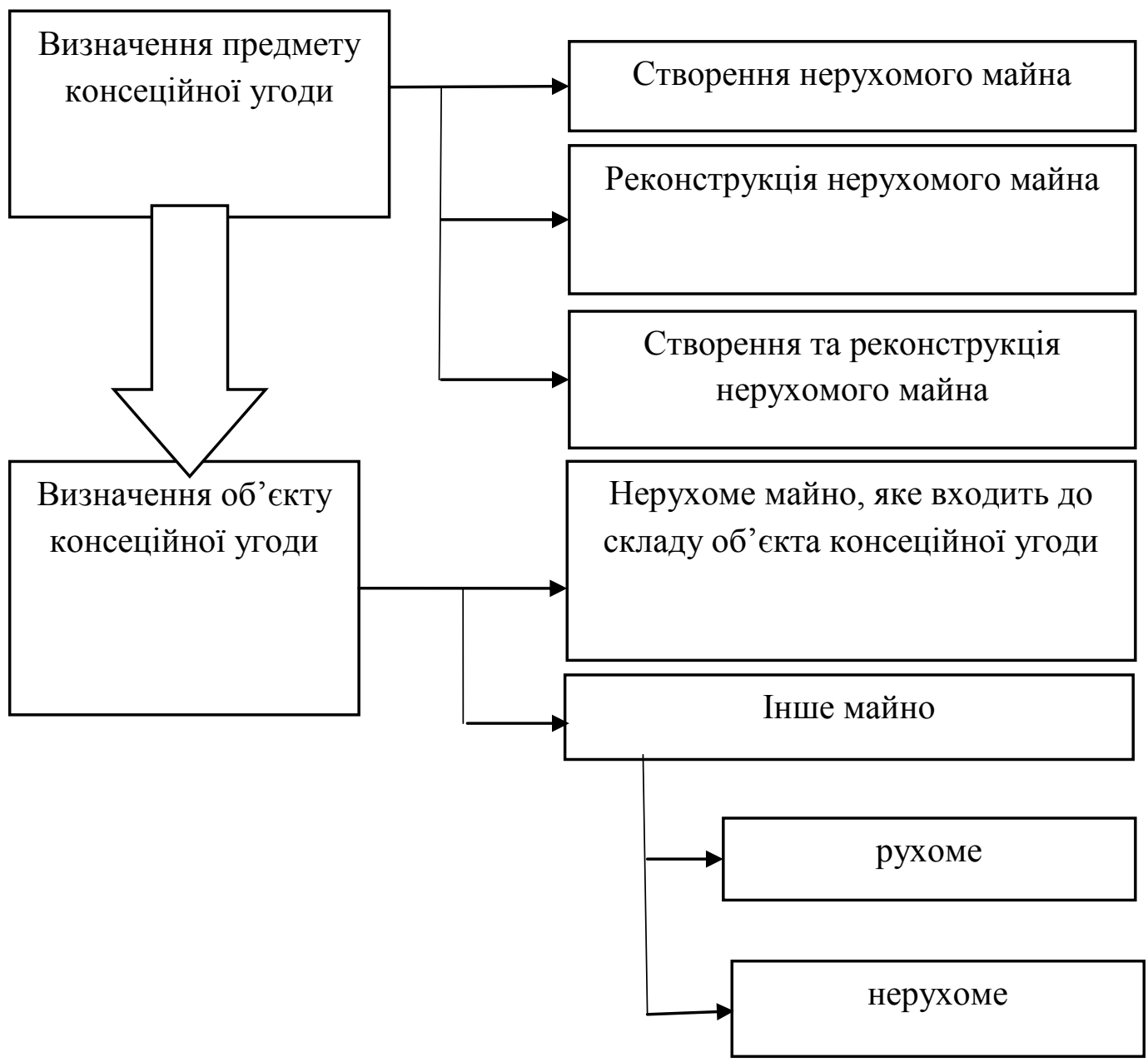

Рис. 2. Основні етапи формування концесійних угод*

Примітка: *Розроблено автором 


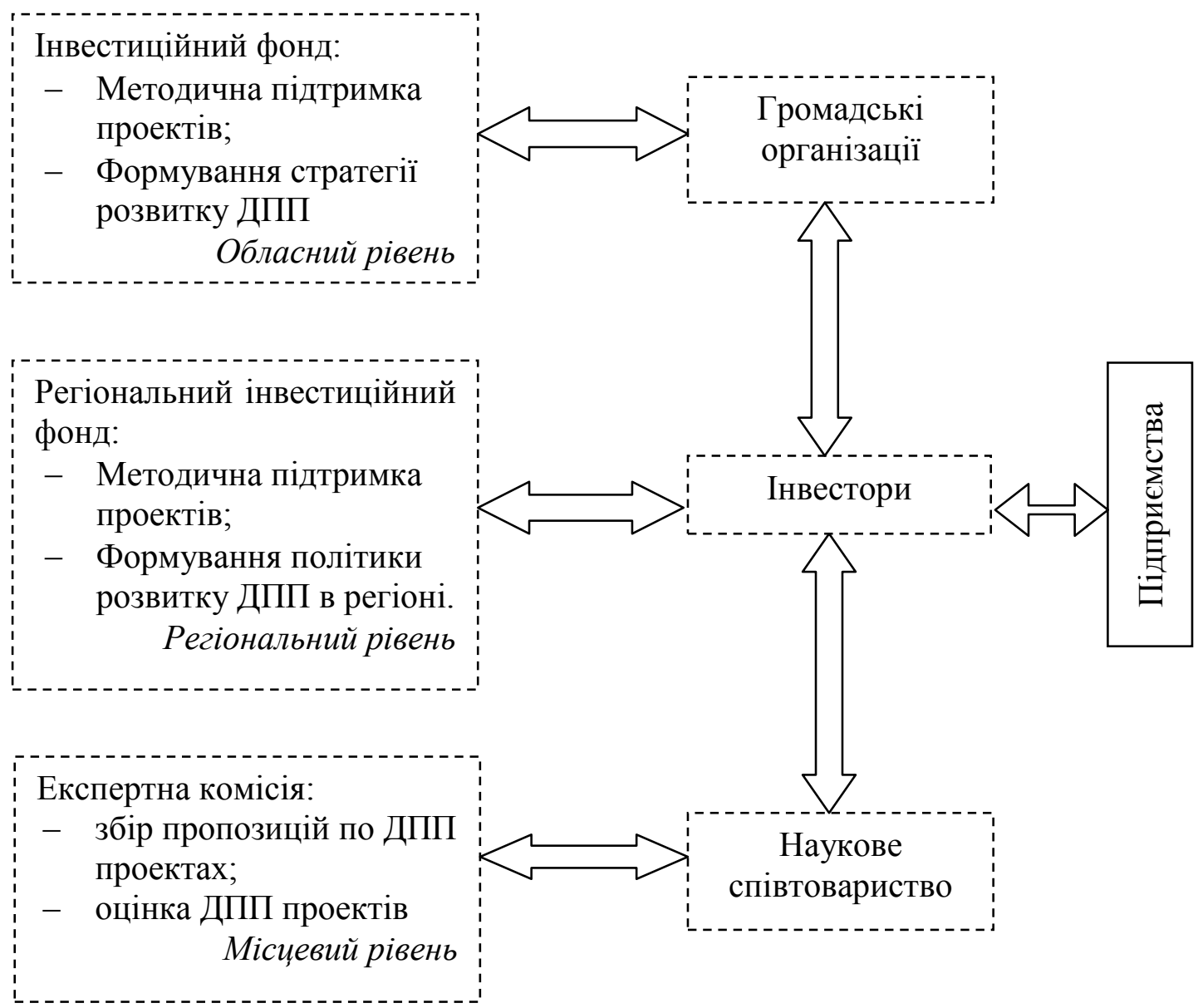

Рис. 3. Модель регулювання діяльності підприємницьких структур через

Примітка: *Розроблено автором реалізацію концесійних угод*

Учасниками розробленої моделі є:

а) органи державної влади:

- обласні;

- регіональні - регіональні інвестиційні фонди;

- органи місцевого самоврядування - експертні комісії. Експертні комісії займаються оцінкою запропонованих ДПП - проектів.

б) інвестори:

- вітчизняні;

- іноземні. Даний аспект особливо важливий. Це обумовлено результатами проведеного аналізу: іноземні інвестиції в агроформуваннях дозволяють підвищити ліквідність та ефективність діяльності;

в) громадські організації - для зняття проблеми відсутності громадського контролю; г) наукове співтовариство - для максимального залучення інноваційних технологій виробництва та управління на вертикально-інтегрованих агропромислових формуваннях;

д) підприємства.

Дана модель передбачає:

1. Наділення органів влади, функціями формування політики та реалізації заходів по розвитку державноприватного партнерства, на всіх рівнях влади, в тому числі і на муніципальному рівні.

2. Взаємодія органів державного та муніципального управління для досягнення максимальної ефективності реалізації проектів державно- приватного партнерства. 
3. Залучення громадських організацій до участі у реалізації проектів державно-приватного партнерства, в тому числі до контролю за їх реалізацією шляхом створення громадських спільнот 3 контролю за реалізацією проектів державно-приватного партнерства.

4. Залучення наукової громади до участі у підготовці, реалізації та моніторингу проектів ДПП.

Процес формування документації для проведення конкурсу та заключення угоди про державно-приватне партнерство - це складний, багаторівневий процес, який потребує розгляду багатьох нюансів та прогнозування економічної та політичної ситуації на довготривалу перспективу. В ході реалізації проекту державно-приватного партнерства можливе виникнення проблем, рішення яких потребує значної зміни умов угоди щодо ДПП. Крім того, процес організації моніторингу якості роботи приватного інвестора також являє досить складним. У зв'язку 3 цим представляється доцільне залучення експертів - представників наукової громади - до участі у підготовці, реалізації та моніторингу проектів державно-приватного партнерства.

Окрім формування інститутів ДПП, необхідно створювати також колегіальні органи 3 питань ДПП на різних рівнях влади, включати представників державних, регіональних та місцевих влад. Окрім владних структур у схожі колегіальні органи повинні бути включені і представники наукової громадськості та громадських організацій. Безумовно, колегіальний орган повинен включати також представників виробництв.

Даний колегіальний орган повинен бути наділений повноваженнями, достатніми для участі у відборі проектів для реалізації в рамках ДПП, розгляди та узгодження документації щодо проведення конкурсів на право заключення угоди про державноприватного партнерства, контроль за діяльністю приватних партнерів та

підготовки пропозицій по коригуванню узгоджень щодо ДПП.

Перспективні

приваблюють ресурсів для свого розвитку, які потребують реалізації лише підтримувальної політики.

\section{Висновки та перспективи}

подальших досліджень. Упродовж останніх років в Україні створено багато програм розвитку біоенергетики та прийнято чимало законів, однак, більшість 3 них фінансово не підтримані, не достатньо продумані, не враховують світовий досвід повністю. Багато країн Свропейського Союзу, США, Бразилія, Австралія та інші, які обрали біоенергетику пріоритетним напрямом розвитку, мають значний досвід становлення законодавчої бази, реалізацію програм сприяння, фінансової підтримки виробництва біопалива.

Отже, 3 метою розвитку ринку біопалива та забезпечення агросфери паливно-енергетичними ресурсами має бути реалізована послідовна системна стратегія, що передбачає податкову підтримку виробництва сумішевих палив, переробку ріпакової олії для промислового використання, розвиток інфраструктури, дотримання екологічних норм 3 раціональним використанням земельних ресурсів з урахування системи сівозмін, кліматичних та соціальноекологічних особливостей регіонів, розробку та створення регіонального біоенергетичного кластеру виробників сільськогосподарської продукції.

Створення

регіональних біоенергетичних кластерів сприяє розвитку інноваційності аграрного сектора, що є механізмом трансформації факторно-орієнтованої моделі економіки країни до більш прогресивної інноваційно-орієнтованої

Отримані авторські результати можуть бути використані у практиці підприємств альтернативної енергетики для вирішення проблем розвитку. 
Пропозиції можуть слугувати теоретичним підгрунтям для подальших досліджень щодо перспектив формування регіонального біопаливного кластеру.

\section{ПЕРЕЛІК ВИКОРИСТАНИХ ДЖЕРЕЛ}

1. Браславец М.Е., Кравченко Р.Г. Математическое моделирование экономических процессов в сельском хозяйстве. М.: Колос, 1972. С.518-519.

2. Варченко О.М., Слупян К.В. Економічний механізм регулювання ринку біопалива у провідних країнах світу. Вісник аграрної науки. 2009. № 11. С. 6267.

3. Водянніков О. Гармонізація національного законодавства України у сфері використання біологічного палива із правом EC.

URL: http://justinian.com.ua/article.php?id=1192.

4. Калінчик М.В., Ільчук М.M. Еластичність попиту на продукти харчування: проблеми, аналіз, прогнозування. К.: Нічлава, 2005. С. 73.

5. Калетнік Г.М. Розвиток ринку біопалив в Україні: автореф. дис. на здобуття наук. ступеня доктора екон. наук: 08.00.03. Економіка та управління національним господарством. К. : ННЦ «IAE», 2009. C. 38.

6. Капшук С. Стан та перспективи українського олієпрому. Пропозиція. 2015. №6. С. 52

7. Месель-Веселяк В.Я. Ефективність енергетичного самозабезпечення сільського господарства. Економіка АПК. 2009. №2. C. 10-14

8. Месель-Веселяк В.Я Паштецький B.С., Грищенко О.Ю. та ін Трансформаційні процеси в сільському господарстві України та Автономної Республіки Крим. Сімферополь: ФОП Лемешко К.О., 2011. С. 120

9. Сотников Е. (2011) Биодизель, биоэтанол, биогаз - технологии и перспективы. URL: http://www.newchemistry.ru/letter.php?n_id= 373.
10. Скорук О.П., Попадюк С.В. Перспективи та економічні передумови виробництва біодизеля в Україні. URL: http://intkonf.org/skoruk-op-popadyuk-svperespektivi-ta-ekonomichni-peredumovivirobnitstva-biodizelya-v-ukrayini.

\section{REFERENCES}

1. Braslavets M.E., Kravchenko R.G. Matematicheskoe modelirovanie ekonomicheskikh protsessov $\mathrm{v}$ sel'skom khozyaystve (2007). [Mathematical modeling of economic processes in agriculture]. Moscow.: Kolos, 1972. pp. 518-519

2. Varchenko O.M., Slupjan K.V. Ekonomichnyj mekhanizm reghuljuvannja rynku biopalyva u providnykh krajinakh svitu [Economic mechanism of regulation of the biofuel market in the leading countries of the world]. Visnyk aghrarnoji nauky. 2009. №11. pp. 62-67

3. Vodiannikov O. Harmonizatsiia natsionalnoho zakonodavstva Ukrainy u sferi vykorystannia biolohichnoho palyva iz pravom EU. [Harmonization of national legislation of Ukraine in the field of biofuels with EU law] URL: http://justinian.com.ua/article.php?id=1192.

4. Kalinchyk M.V., Iljchuk M.M. Elastychnistj popytu na produkty kharchuvannja: problemy, analiz, proghnozuvannja. [Elasticity of demand for food: problems, analysis, forecasting]. Kiev. Nichlava. 2005. p. 73

5. Kaletnik Gh.M. Rozvytok rynku biopalyv $\mathrm{v}$ Ukrajini [Development of the biofuels market in Ukraine]: avtoref. dys. na zdobuttja nauk. stupenja doktora ekon. nauk: 08.00.03. Ekonomika ta upravlinnja nacionaljnym ghospodarstvom. Kiev. NNC «IAE», 2009. p. 38.

6. Kapshuk, S. (2015), Stan ta perspektyvy ukrajinsjkogho olijepromu [The state and prospects of Ukrainian oilseed], Propozytsiia, vol. 6, pp. 52

7. Mesel-Veseliak V.Ia. (2009) Efficiency of energy self-sufficiency of agriculture. Ekonomika APK. №2. pp. 10-14 
8. Mesel-Veseliak V.Ia Pashtetskyi V.S., and prospects] URL: Hryshchenko O.Iu. ta in ( 2011). http://www.newchemistry.ru/letter.php?n_id= Transformatsiini protsesy $\mathrm{v}$ silskomu 373

hospodarstvi Ukrainy ta Avtonomnoi 10. Skoruk O.P., Popadjuk S.V. Respubliky Krym [Transformation processes Perspektyvy ta ekonomichni peredumovy in agriculture of Ukraine and the vyrobnyctva biodyzelja v Ukrajini [Prospects Autonomous Republic of Crimea]. and economic prerequisites for biodiesel Simferopol: FOP Lemeshko K.O., pp. 120 production in Ukraine]. URL:

9. Sotnikov E. (2011) Biodizel. http://intkonf.org/skoruk-op-popadyuk-svbioetanol. biogaz - tekhnologii i perspektivy. perespektivi-ta-ekonomichni-peredumovi[Biodiesel, bioethanol, biogas - technologies virobnitstva-biodizelya-v-ukrayini. 